\title{
WORKSHOP PENYUSUNAN INSTRUMEN PENILAIAN BERBASIS HIGH ORDER THINKING SKILLS (HOTS) DI SDN 44 MATARAM
}

\author{
Ilham Syahrul Jiwandono, Heri Setiawan*, Itsna Oktaviyanti \\ Awal Nur Kholifatur Rosyidah, Baiq Niswatul Khair, Husniati \\ PGSD FKIP Universitas Mataram, Mataram, Indonesia
}

Kata Kunci: instrumen penilaian, HOTS, sekolah dasar

\begin{abstract}
Abstrak: Kurikulum 2013 menuntut guru untuk menguasai berbagai macam penilaian, termasuk penilaian berbasis HOTS. Yang menjadi persoalan, banyak guru yang masih belum menguasai cara pembuatan soal serta penilaian berbasis HOTS. Tujuan kegiatan ini yaitu: (1) memberikan gambaran dan pemahaman yang tepat tentang high order thinking skills (HOTS) serta instumen penilaiannya bagi guru SDN 44 Mataram; (2) meningkatkan kemampuan guru SDN 44 Mataram dalam menyusun instrumen penilaian berbasis HOTS. Metode yang digunakan dalam kegiatan pengabdian kepada masyarakat ini berupa koordinasi, komunikasi, sosialisasi, diskusi, tanyajawab, dan workshop terkait dengan penyusunan Instrumen Penilaian Berbasis High Other Thinking Skills (HOTS) di SD. Secara umum kegiatan pengabdian kepada Masyarakat ini berlangsung dengan baik dan sesuai dengan tujuan dan peserta dapat menyusun instrumen penilaian berbasis Berbasis High Other Thinking Skills (HOTS). Beberapa hal yang dapat direkomendasikan serta dapat ditindaklanjuti berdasarkan kegiatan ini yaitu: (1) penyusunan instrumen penilaian berbasis HOTS dilakukan secara berkesinambungan dan berkelanjutan oleh guru di sekolah; (2) pendampingan yang intensif dari tim dosen pengabdian sebagai bentuk follow up diperlukan agar kegiatan penyusunan instrumen HOTS tidak hanya selesai saat workshop; (3) luasan lingkup kelompok penyusunan instrumen berbasis HOTS pada tingkat KKG ataupun gugus dan adanya pengembangan Bank Soal berbasis HOTS di SD; (4) kepala sekolah diharapkan mampu memfasilitasi dan mendukung guru untuk mengembangkan dan mengaktualisasi kompetensi diri utamanya yang berhubungan dengan K13 dan instrumen penilaian berbasis HOTS di SD.
\end{abstract}

Korespondensi: heri_setiawan@unram.ac.id

\section{PENDAHULUAN}

Kurikulum 2013 atau lebih umum dikenal dengan K13 mulai diterapkan pada tahun 2013. Beberapa tahun berjalan, K13 mengalami berbagai penyempurnaan dan perbaikan. Hal tersebut didasarkan pada kebutuhan dan tuntutan perubahan dalam dunia pendidikan. Salah satu aspek yang dikembangkan dalam K13 yaitu keterampilan abad 21 memfasilitasi empat hal, yaitu: Penguatan Pendidikan Karakter (PPK), 4C (critical thinking, collaboration, creativity, and communication), HOTS, dan literasi.

Salah satu fokus pembaharuan dalam K13 diantaranya membiasakan berfikir kritis kepada siswa SD. Berpikir kritis merupakan keterampilan yang memiliki ciri-ciri sebagai berikut (Rasiman 2013:4); (1) pencarian makna yang melibatkan proses mental untuk memahami suatu pengalaman, (2) menganalisis fakta, menggeneralisasikan, mengorganisasikan ide, menarik kesimpulan dalam menyelesaikan masalah, (3) aktif, 
sistematik untuk memahami dan mengevaluasi argumen. Dengan berbagai cirri-ciri yang telah dipaparkan tampak bahwa berpikir kritis merupakan keterampilan tingkat tinggi, sehingga diperlukan insturmen penilaian yang tepat dan benar-benar dapat mengukur keterampilan berpikir kritis seperti yang diharapkan.

Berfikir kritis perlu dikembangkan bagi siswa SD. Melalui berpikir kritis dapat membantu siswa dalam memahami bagaimana ia menandang dirinya sendiri, bagaimana ia memandang dunia, dan bagaimana ia berhubungan dengan orang lain, membantu meneliti prilaku diri sendiri, dan menilai diri sendiri. Berpikir kritis memungkinkan siswa mampu menganalisis pemikiran sendiri untuk memastikan bahwa ia telah menentukan pilihan dan menarik kesimpulan cerdas. Sedangkan siswa yang tidak berpikir kritis, ia tidak dapat memutuskan untuk dirinya sendiri apa yang harus dipikirkan, apa yang harus dipercaya, dan bagaimana harus bertindak. Karena gagal berpikir mandiri, maka ia akan meniru orang lain, mengadopsi keyakinan dan menerima kesimpulan orang lain dengan pasif (Lambersius, 2009:140-141).

Untuk meningkatkan keterampilan berpikir kritis, siswa memerlukan latihan secara terus menerus dan berkesinambungan. Melalui latihan yang konsisten, dapat membuat keterampilan berpikir kritis menjadi suatu kebiasaan bagi siswa. Berpikir kritis merupakan sebuah kebiasaan berpikir yang seharusnya ditanamkan sejak usia dini. Setiap siswa SD memiliki potensi dan kemampuan untuk menjadi pemikir kritis yang handal.

Salah satu pembiasaan berpikir kritis siswa SD dapat dikembangkan melalui pemberian instrumen berbasis High Order Thinking Skills (HOTS). Melalui soal HOTS siswa diajak untuk menalar, bukan hanya sekedar mengingat, menghafal, atau bahkan mencotek. Soal-soal berbasis HOTS dalam penyusunannya juga memperhatikan dimensi proses berpikir dalam Taksonomi Bloom sebagaimana yang telah disempurnakan oleh Anderson \& Krathwohl (2014), terdiri atas kemampuan: mengetahui (knowing-C1), memahami (understandingC2), menerapkan (applying-C3), menganalisis (analyzing-C4), mengevaluasi (evaluating-C5), dan mengkreasi (creating-C6).

Soal HOTS jika dilihat dari dimensi pengetahuan, umumnya mengukur dimensi metakognitif, tidak hanya mengukur dimensi faktual, konseptual, atau prosedural saja. Dimensi metakognitif menggambarkan kemampuan siswa dalam menghubungkan beberapa konsep yang berbeda, menginterpretasikan, memecahkan masalah (problem solving), memilih strategi pemecahan masalah, menemukan metode baru (discovery), berargumen (reasoning), dan mengambil keputusan yang tepat (Kemendikbud, 2018:228; Amrah, et al, 2018: 527). Dalam taksonomi Bloom, dimensi HOTS masuk pada level menganalisis (analyzing-C4), mengevaluasi (evaluating-C5), dan mengkreasi (creating-C6).

Ketika mengerjakan soal HOTS siswa SD juga diajak untuk: (1) mentransfer informasi tersebut dari satu konteks ke konteks lainnya; (2) memproses dan menerapkan informasi; (3) melihat keterkaitan antara informasi yang berbeda-beda; (4) menggunakan informasi untuk menyelesaikan masalah; serta (5) secara kritis mengkaji/menelaah ide atau gagasan dan informasi (Kemendikbud, 2016:42).

Dalam menyusun soal HOTS disajikan berbagai informasi bagi siswa dalam bentuk stimulus. Stimulus dapat berupa teks, gambar, grafik, tabel, dan lain sebagainya yang berisi informasi-informasi dari kehidupan nyata (Kemendibud, 2017:42). Stimulus yang digunakan 
hendaknya menarik, artinya mendorong siswa untuk membaca dan mendalami soal. Selain itu stimulus hendaknya dekat dengan kehidupan siswa sehingga siswa tidak hanya sekedar paham, namun juga dapat mengaitkan pemecahan masalah yang dirumuskan dengan pemecahan masalah serupa dalam kehidupan sehari-hari.

Guru di lapangan seyogyanya mampu mengembangankan soal berbasis HOTS untuk melatih dan membiasakan siswanya untuk berfikir kritis. Namun dilapangan sebagian besar guru SD masih memiliki kecenderungan mengukur kemampuan berpikir tingkat rendah (LOTS/Lower Order Thinking Skills) dan soal-soal yang dibuat belum kontekstual. Soal-soal yang disusun umumnya masih sekedar mengukur keterampilan mengingat (recall). Konteks yang digunakan sebagian besar konteks di dalam kelas dan sangat teoritis, serta jarang menggunakan konteks di luar kelas. Belum nampak adanya keterkaitan antara pengetahuan yang diperoleh dalam pembelajaran dengan situasi nyata dalam kehidupan sehari-hari (Kemendikbud, 2018:237).

Berdasarkan hasil observasi dan pengamatan awal di SD Negeri 44 Mataram diperoleh fakta bahwa masih banyak kendala yang dihadapi guru dalam menyusun soal berbasis High Order Thinking Skills (HOTS), antara lain sebagai berikut. (1) ketidaksiapan guru melaksanakan pembelajaran dengan kurikulum 2013; (2) kurangnya sosialisasi tentang penerapan Kurikulum 2013; (3) kurangnya pemahaman guru dalam menyusun soal berbasis HOTS; (4) kurangnya pemahaman guru terhadap penilaian sikap, pengetahuan dan keterampilan; (5) belum adanya alat penilaian yang sesuai untuk mengukur keterampilan berpikir kritis (HOTS); (6) guru masih sulit menentukan KD dan tingkatan kelas yang dapat dikembangkan untuk soal HOTS; dan (7) belum banyak sumber dan panduan yang menuntun guru dalam penyusunan soal HOTS di SD.

Berdasarkan uraian di atas, perlu dilakukan kegiatan workshop penyusunan instrumen penilaian untuk guru di SDN 44 Mataram. Pelatihan difokuskan pada peningkatan kemampuan guru-guru dalam menyusun soal-soal penialain berbasis High Order Thinking Skills (HOTS). Diharapkan dari kegiatan pengabdian ini memberikan multieffect. Manfaat bagi guru yaitu memperoleh pengetahuan (insight), terutama dalam keterampilan (skill) menyusun instrumen berbasis HOTS di sekolah dasar. Bagi siswa SD akan memperoleh media pengembangan dan latihan berfikir kritis melalui soal yang dikembangkan oleh guru. Dengan kata lain guru-guru yang telah terampil instrumen penilaian berbasis HOTS diharapkan akan menerapkan ilmunya dalam pembelajaran sehingga siswa SD dibiasakan dan dilatih untuk mengembangkan kemampuan berfikir kritis (critical thinking).

\section{METODE KEGIATAN}

Kegiatan pengambidan ini dilaksanakan dalam bentuk workshop dan pendampingan bagi guru-guru SDN 44 Mataram secara kolaboratif antara tim pengabdian dan guru sasaran dimana tim pengabdian berperan sebagai fasilitator yang bertugas membimbing dan membantu guru dalam proses memahami konsep dan penyusunan soal berbasis HOTS. Setelah workshop tim pengabdian mendampingi guru SDN 44 Mataram dalam menyusun soal berbasis HOTS. 
Metode yang digunakan dalam kegiatan pengabdian kepada masyarakat ini berupa koordinasi, komunikasi, sosialisasi, diskusi, tanya jawab, dan workshop terkait dengan penyusunan Instrumen Penilaian Berbasis High Other Thinking Skills (HOTS).

Kegiatan workshop dilaksanakan pada hari Jum'at 2 Agustus 2019 dalam dua sesi pertama dimulai dari pukul 08.30 sampai pukul 11.00 sedangkan sesi kedua dari pukul 14.00 sampai pukul 16.30 wita. Pada saat sesi pertama dilaksanakan penyampaian materi dan konsep melalui metode ceramah, tanya jawab dan diskusi berbantu LCD dan power point. Metode ceramah dilakukan untuk memberikan pengenalan dan pemahaman guru tentang konsep HOTS lebih dalam, sehingga guru-guru lebih paham tentang teknik dan cara menyusun soal berbasis HOTS. Disamping materi disampaikan secara lisan, peserta juga diberikan salinan materi tentang taksonomi Bloom, format kisi-kisi soal, serta langkahlangkah praktis dalam menyusun soal berbasis HOTS. Metode tanya jawab dilakukan untuk mengetahui sejauh mana pemahaman dan kemampuan guru tentang konsep dan penyusunan soal berbasis HOTS. Metode tanya jawab ini berlangsung selama sesi pertama/proses penyampaian materi dan tidak ada alokasi waktu khusus untuk sesi tanya jawab. Seluruh peserta diberikan kesempatan yang sama untuk bertanya/menyampaikan pendapat. Apabila ada yang belum dipahami diberikan kesempatan mengajukan pertanyaan dan tim dosen menjawab, menjelaskan ulang, ataupun meluruskan konsep sehingga terjadi kesepahaman dan satu pemikiran antara peserta dan pemateri.

Pada sesi kedua dilaksanakan praktek latihan penyusunan soal berbasis HOTS bagi guru. Tim dosen membagi peran dalam mendampingi sehingga peserta pengabdian terdampingi secara maksimal. Guru secara mandiri dibagikan lembar kerja, tim pengabdian kepada masyarat berbagi tugas untuk membimbing guru mulai dari mengidentifikasi $\mathrm{KD}$ yang dapat dikembangkan menjadi soal HOTS, setelah itu guru diajak untuk merumuskan indikator soal HOTS yang hendak disusun, menyusun stimulus dan pembuka soal, hingga di akhir guru mampu menyusun soal berbasis HOTS berdasar KD yang diperoleh. Tim dosen yang berjumlah 6 orang secara terpisah mendampingi masing-masing guru sehingga semua peserta tercover dan apabila terdapat kesulitan dapat langsung diluruskan dan diperbaiki.

\section{HASIL DAN PEMBAHASAN}

Kegiatan ini dilaksanakan pada hari Jum'at tanggal 2 Agustus 2019. Sesi pertama dilaksanakan pada pukul 08.30-11.00 wita dan dilanjutkan sesi kedua pukul $14.00-16.30$ wita. Pengabdian kepada masyarakat ini dilakukan di SDN 44 Mataram dihadiri oleh 6 orang guru dan 1 kepala sekolah. Kegiatan workshop sebelumnya dibuka oleh kepala SDN 44 Mataram dan ketua pelaksana pengabdian kepada masyarakat. Acara dilanjutkan dengan penyampaian materi dan diskusi terkait penyusunan instrumen penilaian berbasis HOTS, adapun rincian kegiatan pelaksanaan yaitu.

Penyampaian materi pertama tentang "Apa Itu High Order Thinking Skills (HOTS)?". Materi pertama disampaikan oleh ibu Awal Nur Kholifatur Rosyidah, M.Pd. Adapun rincian isi materi pertama yaitu: (1) definisi dan pengertian dari HOTS; (2) mengapa siswa di SD perlu dilatih HOTS; (3) kecakapan abad 21 yang harus dikuasai siswa SD; (4) karakteristik HOTS; dan (5) keterkaitan HOTS dengan taksonomi Bloom. Materi awal ini 
perlu disampaikan agar guru dan tim dosen memiliki kesepahaman tentang HOTS. Selain itu juga agar guru benar-benar memahami konsep serta rasionalisasi HOTS di pendidikan dasar.

Materi kedua tentang “Apa itu Taksonomi Bloom?”. Materi ini disampaikan oleh bapak Ilham Syahrul Jiwandono, M.Pd. Isi dari materi ini yaitu : (1) rasionalisasi HOTS di pendidikan dasar; (2) apa itu taksonomi Bloom?; (3) dimensi proses Kognitif; (4) Apa fungsi Taksonomi Bloom dengan soal berbasis HOTS?; dan (5) contoh aplikatif taksonomi Bloom dalam indikator soal HOTS. Materi ini penting diberikan karena kebanyakan guru di lapangan belum paham fungsi dari taksonomi Bloom. Guru lebih banyak mencari perangkat jadi, termasuk instrumen penilaan. Beliau secara praktis belum banyak tahu apa, kapan, dan dimana KKO dalam taksonomi Bloom tersebut digunakan.

Materi ketiga tentang "Bagaimana menyusun kisi-kisi soal yang baik dan benar?”. Materi dsampaikan oleh Ibu Baiq Niswatul Khair, S.Pd., M.Pd. materi ketiga berisi tentang penjabaran: (1) pengertian kisi-kisi soal; (2) tujuan dan fungsi penyusunan kisi-kisi; (3) bentuk kisi-kisi soal; (4) syarat-syarat kisi-kisi yang baik dan benar; dan (5) langkah-langkah penyusunan kisi-kisi soal. Kisi-kisi menjadi bagian yang penting dalam penyusunan instrumen terutama soal-soal bentuk uraian maupun pilihan ganda. Dengan bantuan kisi-kisi guru akan lebih mudah memetakan dan menjabarkan KI dan KD kedalam bentuk evaluasinya.
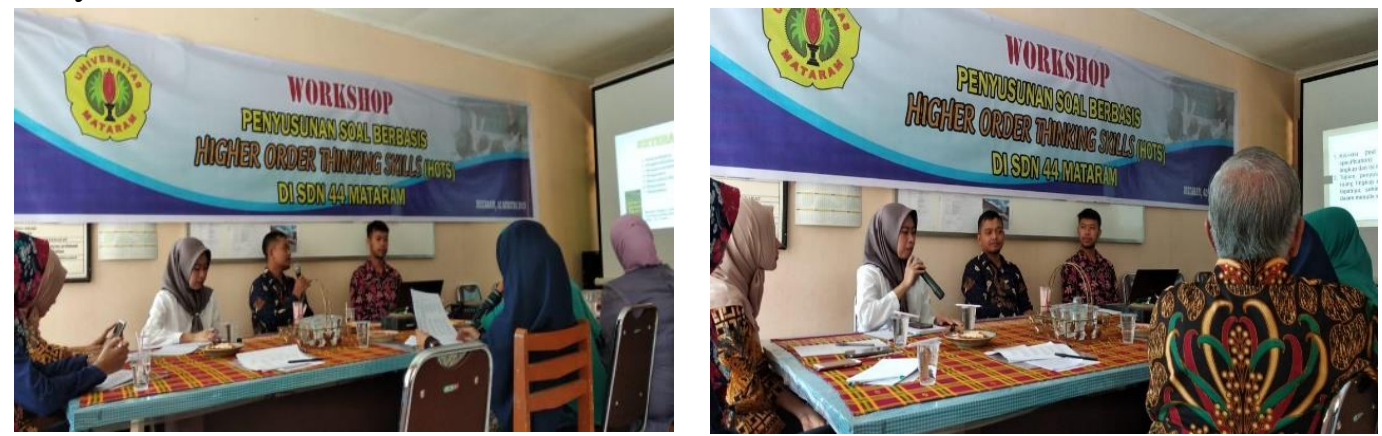

Gambar 1 \& 2. Pelatihan penyusunan Instrumen Penilaian Berbasis High Order Thinking Skills (HOTS) di SD 44 Mataram.

Materi keempat tentang "Langkah-langkah menyusun soal berbasis HOTS". Materi ini disampaikan oleh ibu Husniati, M.Pd dan Ibu Itsna Oktaviyanti, M.Pd. Adapaun dalam pemaparan materi ini guru diberikan gambaran langkah-langkah dalam menyusun soal berbasis HOTS. Adapun langkah tersebut yaitu: (1) menganalisis KD yang dapat dibuatkan soal HOTS. Tidak semua KD dapat dikembangkan sehingga guru harus memahami betul, mana KD yang bisa dan KD mana yang tidak bisa dikembangkan menjadi soal HOTS; (2) menyusun kisi-kisi soal HOTS berdasarkan KD yang telah dianalisis; (3) memilih stimulus yang menarik dan kontekstual; (4) Menulis butir pertanyaan pada kartu soal sesuai dengan kisi-kisi soal. Butir-butir pertanyaan ditulis agar sesuai dengan kaidah penulisan butir soal; dan (5) membuat pedoman penskoran atau kunci jawaban.

Materi terakhir tentang "Contoh-contoh soal HOTS di SD”. Materi ini disampaikan oleh bapak Heri Setiawan, M.Pd sekaligus menutup sesi 1. Contoh-contoh soal HOTS yang disajikan diambil dari beberapa tingkata kelas yaitu kelas 4, 5, dan 6. Soal-soal yang disajikan juga diambil dari berbagai bentuk soal yaitu uraian maupun soal pilihan ganda. 
Tujuan utama pemberian contoh soal ini agar guru lebih memahami konteks yang dibahas dan segi aplikatif dari materi yang dibahas tersebut. Berikut disajikan contoh soal yang diberikan kepada guru.

\section{Mengubah soal tertutup menjadi soal terbuka}

\begin{tabular}{|l|l|}
\hline \multicolumn{1}{|c|}{ Soal Tertutup } & \multicolumn{1}{|c|}{ Soal Terbuka } \\
\hline $\begin{array}{l}\text { Tentukan luas persegi panjang dengan } \\
\text { panjangnya } 5 \mathrm{~cm} \text { dan lebar } 6 \mathrm{~cm} ?\end{array}$ & $\begin{array}{l}\text { Buatlah ukuran panjang dan lebar } \\
\text { persegi panjang jika luasnya } 30 \mathrm{~cm}^{2} ?\end{array}$ \\
\hline Tentukan median dari $3,2,5,7,6 ?$ & $\begin{array}{l}\text { Susunlah angka yang mempunyai rata- } \\
\text { rata nya lebih dari mediannya? }\end{array}$ \\
\hline Berapakah hasil dari $12 \times 3$ & $\begin{array}{l}\text { Sebutkan dua angka yang hasil } \\
\text { perkaliannya adalah } 36 !\end{array}$ \\
\hline
\end{tabular}

Gambar 3. Contoh soal berbasis High Order Thinking Skills (HOTS).

Kegiatan akhir masuk pada sesi 2 dalam workshop ini yaitu guru-guru di SDN 44 Mataram diajak untuk bersama-sama berlatih menyusun soal HOTS di SD. Setiap guru diberikan 1 set KD dari berbagai muatan pembelajaran di SD. Setiap guru didampingi tim dosen, berupaya menentukan apakah KD tersebut bisa dikembangkan untuk soal HOTS atau tidak. Hal ini penting dilaksanakan agar guru memahami bahwa tidak setiap KD bisa dikembangkan menjadi soal HOTS. KD yang dapat digunakan dan dikembangkan menjadi soal HOTS (Kemendikbud, 2018:239) yaitu KD yang memiliki KKO pada tingkat mengnalisis (C4), mengevaluasi (C5), dan mengkreasi (C6).

Tahap kedua guru diajak untuk berlatih indikator soal untuk mengukur HOTS siswa, dengan mengenalkan penggunaani tabel Taksonomi Ranah Kognitif Bloom revisi Anderson, et al (2014:44-45). Guru diajak untuk mengaplikasikan pengetahuan dari materi kedua dalam bentuk praktik. Guru diajak menganalisis, KKO mana yang sesuai dan tepat untuk digunakan dalam insikator soal yang disusun. Setiap guru melakukan analisis dan pengembangan indikator soal, tim dosen hanya mendampingi serta mengarahkan apabila guru mengalami kesulitan.

Tahap ketiga yaitu mengembangkan indikator menjadi soal. Guru diajak untuk menentukan stimulus soal yang berbasis kehidupan sehari-hari (kontekstual). Berdasar indikator yang telah disusun, guru menuangkannya dalam bentuk soal berbasis HOTS. stimulus-stimulus yang dipilih diusahakan sedekat mungkin dengan siswa. Hal ini penting karena memang HOTS mengajak siswa untuk dapat berfikir kritis, memecahkan masalah, serta mencari alternatif pemecahan masalah baru. Dengan stimulus sederhana dan kontekstual, diharapkan siswa terbiasa untuk mampu menerapkan materi yang diperoleh guna menyelesaikan masalah dalam kehidupan sehari-harinya.

Tahap terakhir yaitu perwakilan guru mempresentasikan contoh soal yang dibuat. Guru lain memberikan masukan dan saran melalu diskusi. Melalui tahap ini diharapkan pemahaman guru tentang soal berbasis HOTS menjadi lebih maksimal dan bermakna. Tim 
dosen mendampingi sekaligus memberikan pelurusan konsep \& pemahaman terhadap hasil kerja guru.
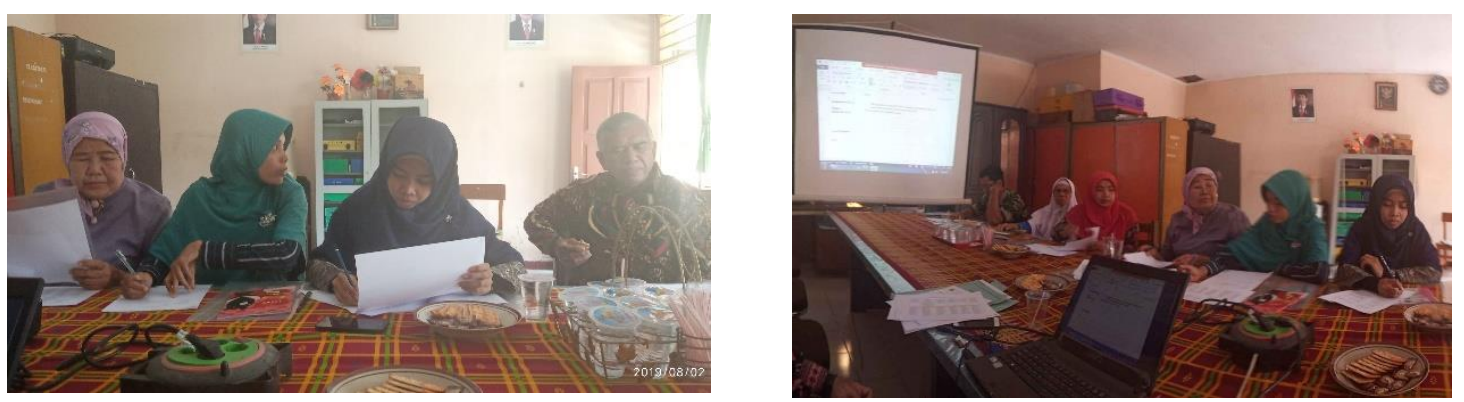

Gambar 4 \& 5. Pendampingan latihan penyusunan Instrumen Penilaian Berbasis High Order Thinking Skills (HOTS) di SD 44 Mataram.

Berdasarkan hasil pengamatan selama berlangsungnya workshop, nampak bahwa sebagian besar peserta pelatihan telah mampu memperlihatkan peningkatan baik dalam hal pemahaman maupun kemampuan meyusun soal berbasis HOTS. Sedangkan sisanya masih perlu mendapatkan latihan dan pendampingan tambahan agar mereka bisa menyusun soal berbasis HOTS bagi siswa di kelas masing-masing. Hasil pengamatan dan pendampingan tersebut didukung dengan hasil tanya jawab dan wawancara lepas terhadap para peserta, sebagian besar mengatakan bahwa kegiatan pengabdian memberikan manfaat bagi mereka. Pengetahuan dan keterampilan tentang soal berbasis HOTS yang didapatkan dalam workshop akan mereka implementasikan baik secara individu maupun secara berkelompok untuk menghasilkan soal-soal berbasis HOTS untuk dijadikan sebagai bahan acuan untuk meningkatkan kualitas pembelajaran di SDN 44 Mataram.

Secara umum kegiatan workshop ini berjalan dengan lancar. Terdapat beberapa faktor yang mendukung kelancaran kegiatan pengabdian ini yaitu: (1) dukungan yang baik dari kepala SDN 44 Mataram dalam bentuk penyediaan tempat pelatihan serta perizinan bagi tim pengabdian; (2) sikap kooperatif dari peserta lokakarya. Para peserta tiba di tempat pelatihan tepat waktu sehingga pelaksanaan workshop dapat berjalan maksimal; dan (3) antusisme peserta cukup tinggi selama mengikuti workshop. Antusisme tampak dari semangat dan pertanyaan yang disampaikan ketika workshop sedang berlangsung dan pengerjaan tugas kelompok sebagai bentuk action \& implementation materi yang disampaikan oleh tim pengabdian. Keadaan ini sangat membantu para peserta dan tim pengabdian belajar dengan optimal. Selain faktor pendukung, terdapat beberapa faktor penghambat yang berarti selama kegiatan workshop berlangsung, yaitu: (1) guru peserta workshop banyak yang belum memiliki pengetahuan awal tentang HOTS dan cara menyusun soal berbasis HOTS sehingga mereka kesulitan mengidentifkasi KD yang dapat dikembangkan menjadi soal HOTS dalam sesi latihan; (2) waktu pelakanaan kegiatan workshop penyusunan soal berbasis HOTS yang terbatas sehingga tidak semua peserta dapat mempresentasikan hasil soal yang mereka susun dalam kegiatan latihan. 


\section{KESIMPULAN DAN SARAN}

Berdasarkan hasil workshop yang telah dilaksanakan maka simpulan dari kegiatan yaitu pelaksanaan kegiatan workshop berjalan sesuai jadwal yang telah direncanakan. Tidak ditemui hambatan dan masalah selama kegiatan dan seluruh anggota tim pengabdian dapat hadir serta partisipasi dan motivasi guru yang cukup baik dalam mengikuti semua kegiatan. Serangkaian kegiatan mulai tahap penyampaian materi hingga pendampingan latihan penyusunan instrumen berbasis HOTS dilakukan secara kolaboratif dan kooperatif baik oleh tim pengabdian maupun guru sebagai peserta.

Beberapa hal yang dapat direkomendasikan serta dapat ditindaklanjuti berdasarkan kegiatan ini yaitu.

1. Kegiatan penyusunan instrumen/soal penilaian berbasis HOTS sebaiknya dilakukan secara berkesinambungan dan berkelanjutan oleh guru di sekolah.

2. Pendampingan yang intensif dari tim dosen pengabdian sebagai bentuk follow up diperlukan agar kegiatan penyusnan instrumen HOTS tidak hanya selesai saat workshop.

3. Peluasan lingkup kelompok penusunan instrumen berbasis HOTS pada tingkat KKG ataupun gugus agar lebih banyak guru terlibat, dan dimungkinkan adanya pengembangan Bank Soal berbasis HOTS di SD.

Kepala sekolah diharapkan mampu memfasilitasi dan mendukung guru untuk mengembangkan dan mengaktualisasi kompetensi diri utamanya yang berhubungan dengan K13, serta mengontrol dan mendampingi guru dalam penyusunan instrumen penilaian HOTS

\section{Ucapan Terima Kasih}

Tim pengabdian kepada masyarakat mengucapkan terima kasih kepada Universitas Mataran yang telah mendanai kegiatan workshop penyusunan soal HOTS bagi guru SDN 44 Mataram melalui dana PNBP tahun 2019 dan tim pengabdian yang telah meluangkan waktu dan tenaga hingga selesai laporan dan artikel ini. Ucapan terima kasih juga disampaikan kepada peserta yaitu guru-guru serta kepala SDN 44 Mataram yang terlibat aktif dan atas kerjasama yang baik dengan tim pengabdian.

\section{DAFTAR PUSTAKA}

Amrah., Nurhaedah., Lutfi., dan Suryani, Erma. 2018. Pelatihan pembuatan soal berbasis HOTS bagi guru di SD Inpres Galangan Kapal IV Kota Makassar. Prosiding Prosiding Seminar Nasional Lembaga Pengabdian Kepada Masyarakat Universitas Negeri Makassar. (ISBN: 978-602-555-459-9), p. 527-529, (Online), (http://ojs.unm.ac.id/semnaslpm /article/viewFile/7803/4557), diakses pada tanggal 29 Agustus 2019.

Anderson, L. \& Krathwohl, D. R. 2001. Kerangka Landasan Untuk Pembelajaran, Pengajaran, dan Asesmen, revisi Taksonomi Pendidikan Bloom. Terjemahan Agung Prihantoro. 2014. Yogyakarta: Pustaka Pelajar.

Kemendikbud. 2017. Panduan Penulisan Soal SD/MI Tahun 2017. Jakarta: Direktorat

Pembinaan Sekolah Dasar Dirjen Dikdasmen Kemendikbud.

Kemendikbud. 2018. Modul Bimbingan Teknis Instruktur Kurikulum 2013 di SD. Jakarta:

Direktorat Pembinaan Sekolah Dasar Dirjen Dikdasmen Kemendikbud. 
Lambertus. 2009. Pentingnya Melatih Keterampilan Berpikir Kritis dalam Pembelajaran Matematika Di SD. Jurnal Forum Kependidikan. 28 (2), p. 136-142.

Rasiman. 2013. Meningkatkan Kemampuan Berpikir Kritis Melalui Pembelajaran Matematika Dengan Pendekatan Matematika Realistik. IKIP PGRI Semarang. 